Pereira, H. G. (1954). J. gen. Microbiol. 10, 500-508.

\title{
The Use of Suspensions of Isolated Cells for the Study of the factors affecting the Multiplication of Fowl-plague Virus
}

\author{
By H. G. PEREIRA \\ Common Cold Research Unit, Harvard Hospital, Salisbury, Wiltshire
}

\begin{abstract}
SUMMARY: The multiplication of fowl-plague virus was studied in cultures prepared with suspensions of isolated cells of chick embryo tissues. Under favourable conditions, virus infectivity increased exponentially for $20 \mathrm{hr}$., after a latent period lasting 4-6 hr. Virus haemagglutinin production varied linearly with the number of cells added to the cultures, the regression line of this relationship showing a slope of approximately 1 when the cell concentration was kept constant and a slope higher than 1 when the number of cells was varied together with the cell concentration. Haemagglutinin production was decreased by increasing the size of the virus inoculum. A similar decrease was observed in cultures in which the depth of the fluid layer was increased. Cultures incubated at $32^{\circ}$ for 2 days showed no haemagglutinin titres. The titres reached in cultures incubated at 35,37 and $39^{\circ}$ did not differ significantly. Cultures kept at $37^{\circ}$ maintained their capacity to support virus multiplication at an approximately constant level for at least 3 days. At $22^{\circ}$ and at $4^{\circ}$ this capacity decreased progressively with time of storage, the decrease being more pronounced at the lower temperature. Virus multiplication was inhibited by horse serum.
\end{abstract}

Suspensions of isolated cells were used by Rous, McMaster \& Hudack (1935) for the study of cell-virus interactions, and more recently by Dulbecco \& Vogt (1953) for investigations on the growth of equine encephalomyelitis and poliomyelitis viruses. The multiplication of fowl-plague virus in cultures prepared with chick embryo cell suspensions was previously reported (Pereira, 1953). These cultures consist of a known number of washed cells suspended in a saline solution of known chemical composition and constitute a system in which some of the factors involved in virus production may be controlled. The object of the present paper is to report the results of the study of some of these factors.

\section{MATERIALS AND METHODS}

Preparation of cell suspensions. The method used for the preparation of chick embryo cell suspensions was based on the technique devised by Shannon, Earle \& Waltz (1952) and modified by Dulbecco (1952). Ten-day chick embryos were collected, decapitated, washed in Gey's (Gey \& Gey, 1936) balanced salt solution (BSS) and minced by means of Craigie's pressure mincer (Craigie, 1949 ) with a coarse plunger $(1 \mathrm{~mm}$. wide grooves). The minced tissue was collected in BSS (3 ml./embryo) and the suspension was left to stand for $10 \mathrm{~min}$. The supernatant was removed and discarded and a $0.5 \%(\mathrm{w} / \mathrm{v})$ solution of trypsin (L. Light and Co. Ltd., Colnbrook, Bucks) in BSS was added to the deposit in the proportion of $3 \mathrm{ml}$./embryo. The tube was placed 
in a water bath at $37^{\circ}$ for $10 \mathrm{~min}$. following which the tissue fragments were broken up by repeated sucking in and out of a syringe fitted with a lumbarpuncture needle. The suspension was then composed almost entirely of isolated cells and the remaining clumps were eliminated by straining through 100mesh Monel wire gauze. The suspension was diluted $1 / 3$ in BSS and then centrifuged for $5 \mathrm{~min}$. at about 1000 r.p.m. The supernatant was discarded and the deposit was washed twice by re-suspension in BSS and centrifugation. The final suspension was again strained through 100-mesh wire gauze. Cell counts were made in a haemocytometer using white cell counting pipette and diluting fluid. Suspensions made in the proportion of $4 \mathrm{ml}$. BSS/10-day embryo contained about $10^{7}$ cells $/ \mathrm{ml}$.

Virus. The 'Dutch' strain of fowl-plague virus was maintained by allantoic passage in 10-day embryonated eggs and the virus-containing allantoic fluids were preserved in sealed capillaries at $-76^{\circ}$. Two batches of capillaries were used throughout these studies, both containing $10^{9 \cdot 7}$ egg infectivity doses $/ \mathrm{ml}$.

Virus titrations. (a) Haemagglutination tests were performed by a pattern technique using $\mathbf{0 . 2} \mathrm{ml}$. of twofold dilutions of the virus preparation to which were added equal volumes of a $0.5 \%(v / v)$ suspension of washed chicken red cells. The results were expressed as the log of the number of agglutinating doses (AD) present in the total volume of each culture, one AD corresponding to the amount of virus capable of causing $\mathbf{5 0} \%$ agglutination of the red cells contained in $\mathbf{0 . 2} \mathrm{ml}$. of the suspension.

(b) Egg infectivity tests were performed by the inoculation of $0.05 \mathrm{ml}$. of tenfold dilutions of the virus preparations in broth saline into the allantoic cavity of 10-day embryonated eggs. Each dilution was inoculated into four eggs and the end-point was calculated by the method of Reed \& Muench (1938). The results were expressed as the log of the number of $50 \% \mathrm{egg}$ infectivity doses (EID 50) present in the total volume of each culture.

Preparation of cultures. The cultures were set up in $3 \times \frac{5}{8}$ in. tubes, stoppered with rubber bungs, sloped at an angle of about $5^{\circ}$ from the horizontal and incubated at $37^{\circ}$. The total volume was adjusted to $1 \mathrm{ml}$. These conditions were kept constant unless otherwise specified. Penicillin and streptomycin were added to all the cultures to give a final concentration of 50 units and $50 \mu \mathrm{g} . / \mathrm{ml}$., respectively. In the growth-curve experiment the cultures were set up in $2 \mathrm{ml}$. ampoules which were sealed, sloped and incubated. At appropriate intervals, groups of 3 ampoules were frozen and preserved in solid $\mathrm{CO}_{2}$. At the time of titration each culture was thawed in a water bath at $37^{\circ}$, its contents were lightly centrifuged and the supernatant was titrated by egg infectivity.

\section{RESULTS}

The growth curve of fowl-plague virus

The curve of infectivity production in cultures started with $10^{6.8}$ cells and $10^{4 \cdot 7}$ EID 50 of fowl-plague virus is shown in Fig. 1. The number of EID50 detected at time 0 corresponded to about $5 \%$ of the amount inoculated. Additional experiments revealed that $80 \%$ of the infectivity of the inoculum 
was lost as a result of the process of freezing and thawing and an additional $15 \%$ was retained in the deposit of the cultures. The infectivity was further decreased to about $1 \%$ of the inoculum after $4 \mathrm{hr}$. of incubation and then increased exponentially for $20 \mathrm{hr}$. At 40 and $48 \mathrm{hr}$. the infectivity was only slightly higher than at $24 \mathrm{hr}$. In another experiment in which cultures were tested after 2,4 and $6 \mathrm{hr}$. of incubation the period of low infectivity was shown to last between 4 and $6 \mathrm{hr}$.

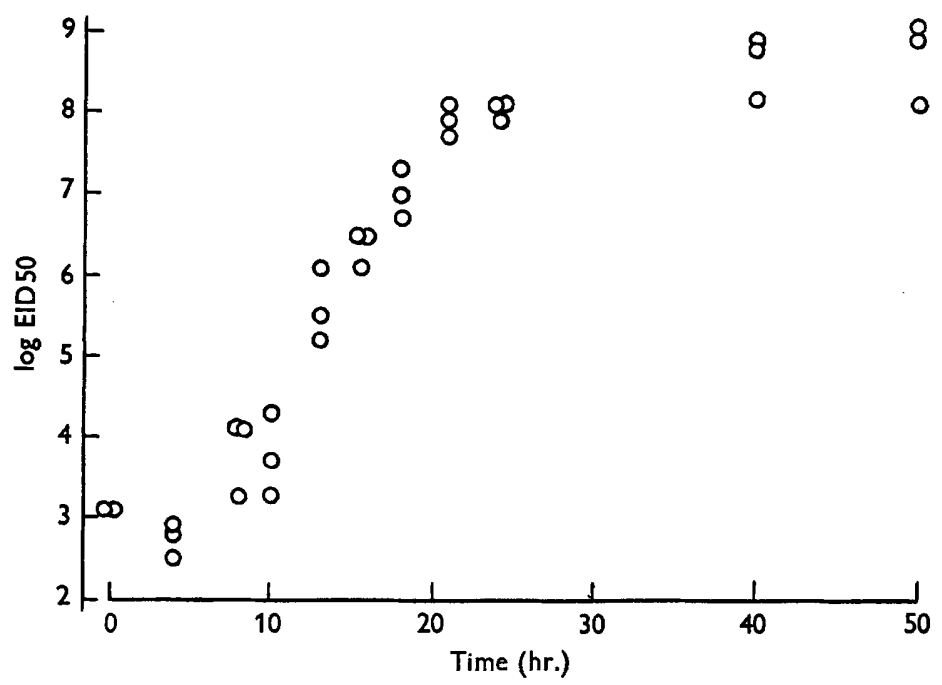

Fig. 1. Growth curve of fowl-plague virus in cell suspension cultures.

\section{Number of cells}

Two series of experiments were performed to study the relationship between the number of cells present in the cultures and the amount of virus produced. In the first series the number of cells in successive groups of tubes was varied, together with the total volume of fluid, the concentration being constant in all the tubes $\left(10^{6 \cdot 7}\right.$ cells $/ \mathrm{ml}$.). In the second series the number of cells was varied, together with the cell concentration, the volume of fluid being constant in all the cultures $(1 \mathrm{ml}$.). In all these experiments the total number of cells was varied in the region between $10^{6}$ and $10^{7}$. The virus inoculum was added to all the cultures in a final dilution of $10^{-5}\left(10^{4 \cdot 7} \mathrm{EID} \mathrm{50} / \mathrm{ml}\right.$.). The tubes were slanted, incubated at $37^{\circ}$ for 2 days, following which the supernatants were titrated by haemagglutination. The results are shown in Figs. 2 and 3, in which each point corresponds to the average of four determinations. In both series a linear relationship was observed between the number of cells present in the cultures and the amount of haemagglutinin produced. The slopes of the regression lines gave values of $\mathbf{0 . 9 9 8}$ for the series with constant cell concentration and 1.709 for the series with varying cell concentrations. A $t$-test between the two slopes showed that they are significantly different $(t=4 \cdot 29$ with 51 D.F., $P<0.001$ ). The possibility that the increased virus production in high cell concentrations might be due to a stimulation by substances derived 
from the embryo and improperly washed away in the process of preparation of the suspension was considered. A suspension was prepared by the usual technique except that the cells were washed by four cycles of centrifugation and resuspension instead of three. Cultures prepared with constant numbers of cells suspended in the three last supernatants obtained in the washing process and in BSS revealed no difference in virus-producing capacity.

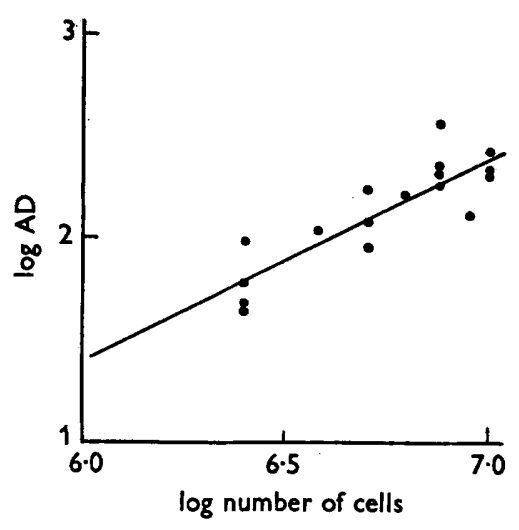

Fig. 2. Relation between number of cells and haemagglutinin production. Constant cell concentration. Varying volumes.

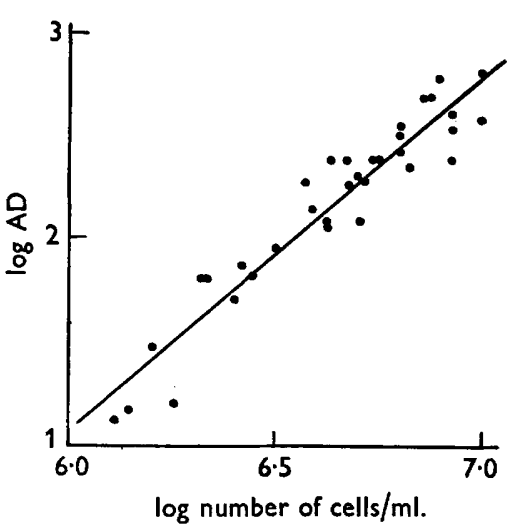

Fig. 3. Relation between number of cells and haemagglutinin production. Varying cell concentrations. Constant volume.

\section{Size of the virus inoculum}

Two groups of sixteen tubes, each containing $10^{6 \cdot 7}$ cells, were inoculated respectively with $10^{6 \cdot 7}$ and $10^{3 \cdot 7}$ EID50 of fowl-plague virus. The volume was adjusted to $1 \mathrm{ml}$. in all the tubes. After 2 days of incubation under standard conditions the supernatant fluid of each culture was titrated by haemagglutination. The average log of the number of $\mathrm{AD}$ produced per tube was calculated for each series. For the series receiving the larger virus inoculum this value was 1.83 with a standard deviation of 0.08 and for the series receiving the smaller virus inoculum it was $2 \cdot 21$ with a standard deviation of 0.11 . A $t$-test between these two averages showed a significant difference $(t=10 \cdot 21$ with 30 D.F., $P<0.001)$.

\section{Temperature of incubation}

Four groups of twelve cultures were prepared, each tube containing $10^{6.7}$ cells and 10.7 EID 50 of fowl-plague virus. The different groups were incubated respectively at temperatures of $32,35,37$ and $39^{\circ}$. After 2 days the supernatant fluid of each culture was titrated by haemagglutination and the results obtained for each group were averaged. Table 1 summarises the results. In the cultures incubated at $\mathbf{3 2}^{\circ}$ no haemagglutinating activity was detected after 2 days of incubation. The average $\log \mathrm{AD}$ of the groups of cultures incubated at 35,37 and $39^{\circ}$ were not significantly different. 
Table 1. Influence of temperature of incubation on virus haemagglutinin production

$\begin{array}{ccc}\begin{array}{c}\text { Temperature of } \\ \text { incubation }\end{array} & \begin{array}{c}\text { Average } \\ \text { log AD }\end{array} & \begin{array}{c}\text { Standard } \\ \text { deviation }\end{array} \\ \left(^{\circ}\right) & <\mathbf{0 \cdot 6 7} & - \\ \mathbf{3 2} & \mathbf{2 \cdot 3 1} & \mathbf{0 \cdot 2 4} \\ \mathbf{3 5} & \mathbf{2 \cdot 2 4} & \mathbf{0 \cdot 1 4} \\ \mathbf{3 7} & \mathbf{2 \cdot 3 7} & \mathbf{0 \cdot 1 2}\end{array}$

\section{Depth of fluid layer}

Two groups of sixteen cultures were prepared, each tube containing $10^{6 \cdot 7}$ cells and $10^{3 \cdot 7}$ EID 50 of fowl-plague virus. The first group was set up in $4 \times \frac{1}{2}$ in. tubes which were incubated upright, the fluid forming a column about $15 \mathrm{~mm}$. high. The second group was set up in $3 \times \frac{5}{8}$ in. tubes which were incubated at an angle of $5^{\circ}$ from the horizontal, the fluid column at its deepest part showing a height of about $3 \mathrm{~mm}$. After 2 days incubation at $37^{\circ}$ the supernatant fluid of each culture was titrated by haemagglutination. The average $\log$ of the number of $\mathrm{AD}$ produced per tube gave values of 1.59 with a standard deviation of 0.19 for the cultures with deep fluid layer and $2 \cdot 21$ with a standard deviation of $\mathbf{0} \cdot 11$ for the cultures with shallow fluid layer. A $t$-test between these two averages showed a significant difference $(t=11.06$ with 30 D.F., $P<0.001$ ).

\section{Storage of cell suspension}

The effect of storage at different temperatures on the capacity of the cell suspension to support virus multiplication was investigated. Thirty cultures were prepared containing $10^{6.8}$ cells in a volume of $0.9 \mathrm{ml}$. Three tubes were immediately inoculated with $10^{4.7}$ EID 50 of fowl-plague virus in a volume of $0.1 \mathrm{ml}$. and incubated at $37^{\circ}$. The remaining tubes were divided into three groups which were sloped and kept at 4,22 and $37^{\circ}$ respectively. After $24 \mathrm{hr}$. three tubes of each group were inoculated with fowl-plague virus as above and incubated at $37^{\circ}$. At 48 and $72 \mathrm{hr}$. further groups of tubes were treated similarly. After addition of the virus the tubes were incubated at $37^{\circ}$ for 2 days and then preserved at $4^{\circ}$ until the end of the experiment, when the supernatant fluid of each culture was titrated by haemagglutination. The result is shown in Fig. 4 in which each point represents the average log AD of the three tubes of each group. The virus-producing capacity of the cultures kept at $37^{\circ}$ remained approximately constant up to $72 \mathrm{hr}$. At 22 and at $4^{\circ}$ the virusproducing capacity decreased progressively with the time of storage, this decrease being more pronounced at the lower temperature. In the cultures kept at $37^{\circ}$ the cells were observed to adhere to the glass forming a rather irregular sheet containing many fibroblast-like elements.

\section{Inhibitory action of horse serum}

Six groups of four cultures were prepared containing $10^{6 \cdot 8}$ cells and $10^{4 \cdot 7}$ EID 50 of fowl-plague virus. To five of the six groups unheated normal horse serum was added at concentrations varying from 2 to $10 \%$ and to the remaining group no horse serum was added. After 2 days of incubation under 
standard conditions the supernatant fluid of each culture was titrated by haemagglutination. The result is shown in Fig. 5 in which each point represents the average log $\mathrm{AD}$ of each group. These values decrease linearly with increasing concentrations of horse serum. At the end of the incubation period all the cultures showed a layer of cells adhering to the wall of the tube. In

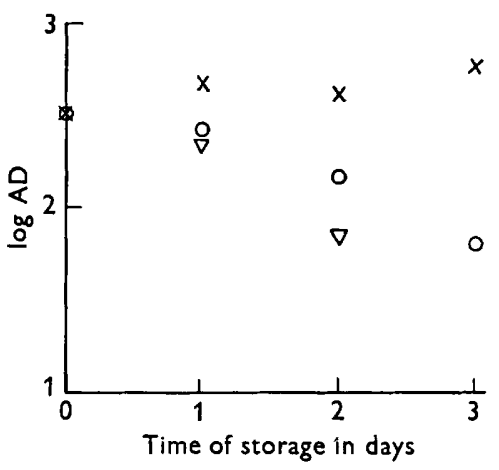

Fig. 4. Effect of storage at different temperatures on the virus-producing capacity of cell suspension cultures. $\times$, cultures stored at $37^{\circ}$ before addition of virus; $O$, cultures stored at $22^{\circ}$ before addition of virus; $\nabla$, cultures stored at $4^{\circ}$ before addition of virus.

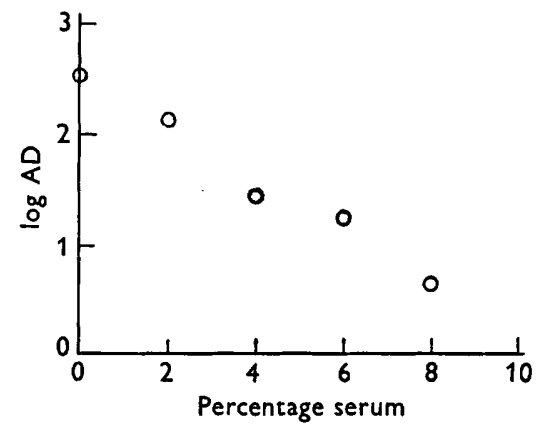

Fig. 5. Inhibition of haemagglutinin production by normal horse serum.

the cultures without serum this layer was very irregular and revealed on microscopic examination very few intact cells. As the serum concentration increased the cellular layer showed increasing numbers of fibroblast-like elements. Further investigation demonstrated that the factor in horse serum responsible for this inhibition resisted heating at $56^{\circ}$ for $30 \mathrm{~min}$. and was inactivated by trypsin.

\section{COMMENTS}

The study of the factors influencing the growth of viruses in tissue cultures was reviewed by Robbins \& Enders (1950). The interpretation of the results obtained has often been complicated by the imperfect standardization of some of the factors studied, because of technical difficulties. With the object of achieving this standardization the cultures used in the present study were started with suspensions of isolated cells. The virus of fowl-plague multiplies readily in this system reaching relatively high haemagglutination titres which proved of great value for the simultaneous titration of relatively large numbers of culture materials.

The growth of fowl-plague virus in cell suspension cultures revealed several features in common with other viruses studied under similar conditions (Crawford \& Sanders, 1952; Gajdusek, 1953; Womack \& Kass, 1953). A latent period of 3-5 hr. followed by a stepwise increase of infectivity was reported by Schäfer \& Munk (1952) in the case of the multiplications of fowl-plague virus on the isolated chorio-allantoic membrane of chick embryos. The heterogeneous nature of the cell suspension used in the present study prevented the 
estimation of the multiplicity of infection and, as no attempts were made to prevent re-infection of cells by newly formed virus, no evidence for a stepwise growth cycle could be obtained. Dulbecco \& Vogt (1953) described onestep growth curves of poliomyelitis and Western equine encephalomyelitis viruses in cell suspensions.

The relationship between number of cells and virus production in tissue cultures has been studied by several authors (Hallauer, 1932; Plotz, 1933; Rivers \& Ward, 1933; Traub, 1933; Fox, 1947; Yanamura \& Meyer, 1941; Simms \& Sanders, 1942; Ledinko, Riordan \& Melnick, 1952; Womack \& Kass, 1953). In most of these studies the number of cells was estimated by indirect methods such as the weight, the volume or the nitrogen content of the tissue added to the cultures. The results varied for different systems, but in general it has been found that there is an optimum amount of tissue for maximal virus production. The use of suspensions of isolated cells provides particularly favourable conditions for the study of this relationship, as by this method the number of cells may be estimated by direct count and replicate cultures may be prepared. In the region covered by our experiments a linear relationship was observed between the number of cells added to the cultures and the amount of virus haemagglutinin produced. The fact that with constant cell concentrations the regression line of this relationship shows a slope of approximately $1(0.998)$ indicates that under these experimental conditions the virus concentrations obtained are constant for each cell concentration and independent of the total volume of the culture. Under these conditions it may be assumed that throughout the range studied the same average amount of virus haemagglutinin was produced by individual cells. On the other hand, when the number of cells was varied, together with the cell concentration, the slope of the cell-virus regression line gave a value higher than 1 (1.709) indicating that the average amount of virus produced per cell increases with increasing cell concentrations. This fact may represent another manifestation of cellular interactions described for several tissue culture systems (Buchsbaum, 1932; Ephrussi, 1933; Bloom, 1937; Fischer \& Jensen, 1946; Earle et al. 1951). It is possible that cellular products diffused into the medium during the period of incubation may favourably influence virus production. The low sensitivity of the haemagglutination test used for virus titrations established the lower limit of cell concentrations studied, as the virus yields in suspensions containing less than $10^{6}$ cells $/ \mathrm{ml}$. do not reach haemagglutination level. Dulbecco \& Vogt (1953), who used a plaque technique of titration, demonstrated the multiplication of poliomyelitis and Western equine encephalomyelitis viruses in isolated cells. These authors' techniques differed from ours in that the cells were suspended in a nutrient medium.

It should be noted that in the series of experiments in which the total volume of the cultures was varied, the depth of the fluid column was kept low by sloping the tubes during incubation. This precaution was taken in view of the observed decrease of virus yield in cultures in which the fluid column is deep. The influence of the depth of the fluid column on virus production in tissue cultures was studied by Maitland, Laing \& Lyth (1932), Yanamura \& Meyer (1941), Thompson \& Coates (1939), and the results have varied for the different 
systems under study. The use of shallow fluid layers is a procedure generally adopted in tissue culture work.

The influence of the size of inoculum on virus production in tissue cultures has been studied by several authors (Fox, 1947; Yanamura \& Meyer, 1941; Womack \& Kass, 1953; Sanders \& Jungeblut, 1942; Dulbecco \& Vogt, 1953), and in general it has been observed that the final titres obtained are not greatly affected by the size of the inoculum but the time required for maximal virus production is increased when small inocula are used. Robbins, Weller \& Enders (1952), when studying the propagation of poliomyelitis viruses in roller tube cultures of human tissues, obtained relatively smaller titres in cultures inoculated with large amounts of virus. A similar result was clearly demonstrated in the present investigation. Kinetic studies of virus multiplication in cultures started with varying sizes of inoculum are necessary for a better understanding of this phenomenon.

The study of the effect of storage on the capacity of cell suspensions to support virus growth revealed that this property is preserved for longer periods at $37^{\circ}$ than at room temperature or at $4^{\circ}$. This result might be explained in part by the occurrence of cellular multiplication at $37^{\circ}$. Cultures incubated at this temperature before addition of the virus revealed after 2 days an irregular sheet of fibroblast-like cells adhering to the glass. In virus-infected cultures the number of these cells was greatly reduced. The cellular sheet of cultures incubated for 2 days in the absence of virus revealed no mitotic figures on microscopical examination after fixation and staining by haematoxylin in situ.

The composition of the medium was shown to have a marked effect on the appearance of the cellular sheet formed after incubation. Increasing numbers of fibroblast-like elements were observed in cultures containing increasing concentrations of horse serum. This action of horse serum was accompanied by inhibition of virus haemagglutinin production. The mechanism of this inhibition cannot be explained as due to the depressive action of horse serum on cellular physiological activities as proposed by Fox (1947) for the inhibition of the multiplication of yellow fever virus in tissue cultures.

The author wishes to thank Miss M. V. Mussett for help in the statistical analysis of the results.

\section{REFERENCES}

Bцoom, W. (1937). Cellular differentiation and tissue culture. Physiol. Rev. 17, 589. Buchsbaum, R. M. (1932). Size of explant and volume of medium in tissue cultures. J. exp. Zool. 63, 483.

Craigie, J. (1949). A pressure mincer for the preparation of tumour suspensions. Brit. J. Cancer, 3, 249.

Crawford, G. N. C. \& Sanders, F. K. (1952). The multiplication of vaccinia virus in tissue cultures of adult rabbit skin. Quart. J. micr. Sci. 93, 119.

Dulbecco, R. (1952). Production of plaques in monolayer tissue cultures by single particles of an animal virus. Proc. nat. Acad. Sci., Wash., 38, 747.

Dulbecco, R. \& Vogt, M. (1953). Interaction of Viruses and Cells. Symposium of the Sixth International Congress of Microbiology. Rome: Fondazione Emanuele Paterno.

Earle, W. R., Sanford, K. K., Evans, V. J., Waltz, H. K. \& Shannon, J. E. (1951). The influence of inoculum size on proliferation in tissue cultures. J. nat. Cancer Inst. 12, 133. 
Ephrussi, B. (1933). Croissance et régéneration dans les cultures des tissues. Arch. Anat. micr. 29, 95.

Fischer, A. \& Jensen, A. B. (1946). Growth limiting factors of tissue cells in vitro. Acta physiol. scand. 12, 218.

Fox, J. P. (1947). The cultivation of yellow fever virus. I. Factors influencing the multiplication of $17 \mathrm{D}$ virus in tissue culture. Amer. $J$. Hyg. 46, 1.

GaJdusek, D. C. (1953). Suspended cell tissue cultures for study of virus growth kinetics. Proc. Soc. exp. Biol., N.Y. 83, 621.

Gey, G. O. \& Gey, M. K. (1936). The maintenance of human normal cells and tumor cells in continuous culture. I. Preliminary report: cultivation of mesoblastic tumors and normal tissues and notes on methods of cultivation. Amer. J. Cancer, 27, 45.

Hallauer, C. (1932). Über das Verhalten von Hühnerpestvirus in der Gewebekultur. Z. Hyg. InfektKr. 113, 61.

Ledinko, N., Rrordan, J. T. \& Melnick, J. L. (1952). Multiplication of poliomyelitis viruses in tissue cultures of monkey testes. I. Growth curves of type 1 (Brunhilde) and type 2 (Lansing) strains and description of a quantitative neutralization test. Amer. J. Hyg. 55, 323.

Maitland, H. B., Laing, A. W. \& LyTh, R. (1932). Observations on the growth requirements of vaccinia virus in vitro. Brit. J. exp. Path. 13, 90.

Pereira, H. G. (1953). Multiplication of fowl plague virus in chick-embryo cell suspensions. J. Path. Bact. 65, 259.

Plotz, H. (1933). Influence de la quantité des cellules embryonnaires sur la culture du virus de la peste aviare. C.R. Soc. Biol., Paris, 113, 1336.

ReEd, L. J. \& Muench, H. (1938). A simple method of estimating fifty per cent end-points. Amer. J. Hyg. 27, 493.

RIvers, T. M. \& WARD, S. M. (1933). Observations on the cultivation of vaccinia virus in lifeless media. J. exp. Med. 57, 51.

Robbins, F. C. \& Enders, J. F. (1950). Tissue culture techniques in the study of animal viruses. Amer. J. med. Sci. $220,316$.

Robbins, F. C., Weller, T. H. \& Enders, J. F. (1952). Studies on the cultivation of poliomyelitis viruses in tissue culture. II. 'The propagation of the poliomyelitis viruses in roller tube cultures of various human tissues. J. Immunol. 69, 673.

Rous, P., McMaster, P. D. \& Hudack, S. S. (1935). The fixation and protection of viruses by the cells of susceptible animals. J. exp. Med.61, 657.

Sanders, M. \& Jungeblut, C. W. (1942). Studies in rodent poliomyelitis. II. Cultivation of the murine strain of SK poliomyelitis virus. J. exp. Med. 75, 631 .

SchäFER, W. \& MUNK, K. (1952). Eigenschaften tierischer Virusarten, untersucht an den Geflügelpestviren als Modell. IV. Mitt. Untersuchungen über den Ablauf der Vermehrung beim Virus der klassischen Geflugelpest. Z. Naturf. 76, 608.

Shannon, Jr., J. E., Earle, W. R. \& Waltz, H. K. (1952). Massive tissue cultures prepared from whole chick embryos planted as a cell suspension on glass substrate. J. nat. Cancer Inst. 13, 349.

Simms, H. S. \& SANDERS, M. (1942). Use of serum ultrafiltrate in tissue cultures for studying deposition of fats and for propagation of viruses. Arch. Path. (Lab. Med.), 33, 619.

Thompson, R. L. \& Coates, M. S. (1939). The cultivation of vaccinia virus in deep columns of Maitland medium. J. infect. Dis. 64, 105.

Traub, E. (1933). Cultivation of Pseudorabies virus. J. exp. Med. 58, 663.

Womack, C. R. \& Kass, E. H. (1953). Influenza virus in allantoic sac culture. Quantitative studies on nucleic acid content during growth and in the presence of cortisone. J. Immunol. 71, 152.

Yanamura, H. Y. \& MeYer, K. F. (1941). Studies on the virus of psittacosis cultivated in vitro. J. infect. Dis. 68, 1. 